\title{
ANALYSIS OF HIKING FOOD PROCESSING TECHNOLOGIES ON THE MARKET
}

\section{Inese Silicka1, Iveta Dembovska², Erika Teirumnieka ${ }^{3}$, Ivo Dembovskis 4}

\author{
${ }^{1}$ Mg.soc.sc., lecturer, researcher, Rezekne Academy of Technologies, Rezekne, Latvia, \\ e-mail: inese.silicka.@rta.lv \\ 2 Mg.oec., lecturer, researcher, Rezekne Academy of Technologies, Rezekne, Latvia, \\ e-mail: iveta.dembovska@rta.lv \\ ${ }^{3}$ Mg.chem., lecturer, researcher, Rezekne Academy of Technologies, Rezekne, Latvia, \\ e-mail: erika.teirumnieka@rta.lv \\ ${ }^{4}$ Mg.soc.sc., chairman of the board, Ltd."Projektēšanas birojs Austrumi", Rezekne, Latvia, \\ e-mail: Ivo.Dembovskis@gmail.com
}

Received: 10 October 2020 / Revised: 17 October 2020 / Accepted: 6 November 2020 /

Published: 30 November 2020

\begin{abstract}
The food sector is one of the fastest growing sectors, therefore it requires that producers follow food market trends and quickly respond to consumer demand. Besides, the producers have to comply with the increasingly strict conditions and regulations imposed on food producers in recent years. Food producers need to be able to develop products that are safe and have a long shelf life and at the same time, the manufacturers have to continuously diversify their products, create new flavour and aroma combinations, increase the nutritional value of the products while increasing the production volumes and considering energy efficiency, as well as environmental impact. The aim of the research is to study and analyse hiking food processing technologies on the market. Methods used in the research - monographic, synthesis, the comparative method. The research developed proposals for manufacturers of hiking food for the design and manufacturing of new products.
\end{abstract}

Keywords: drying, hiking food, lyophilisation equipment, processing technologies. JEL code: 014, L66.

\section{Introduction}

Food producers need to be able to develop products that are safe and have a long shelf life and at the same time, the manufacturers have to continuously diversify their products, create new flavour and aroma combinations, increase the nutritional value of the products while increasing the production volumes and considering energy efficiency, as well as environmental impact. Therefore, the range of research on the development of new technologies in the food industry is constantly expanding (Galoburda et al., 2008).

The aim of the research is to study and analyse hiking food processing technologies on the market.

To achieve the research aim, the authors have set the following specific research tasks: 1) study food processing technologies; 2) make a comparison

http://dx.doi.org/10.17770/jresd2020vol1.12.5398

This is an open access article under the Creative Commons Attribution 4.0 International License 
of different drying technologies; 3) research the lyophilization equipment market; 4) make conclusions and recommendations.

Research period: 2019-2020.

Hypothesis: The use of lyophilization technology in the production of hiking food allows achieving longer preservation of the products, easier transportation, high dehydration capacity.

Research novelty: The study of food processing technologies and comparison of different drying technologies, research on the lyophilization equipment market.

Research methods: monographic, synthesis, the comparative method.

\section{Research results and discussion}

In Latvia, the main challenge for farmers in the food sector is to be able to efficiently process primary agricultural products (fruits, berries, meat) with a short shelf life, while maintaining their biological and economic value and doing it with small investments. One of the possible solutions is the processing of products with drying methods that have historically been used over a long period of time both in Latvia and abroad. However, until now most of the widely used methods dry fruits, berries, and meat with a residual moisture content that is well above $5 \%$. At this level of moisture, the products cannot be stored for a long time with the retention of their biological properties and must be stored in closed containers under prescribed conditions. Such products are not mold-resistant. A possible solution is lyophilization or freeze drying.

A mindful food acquisition and its efficient preparation is crucial in ensuring that the planet's resources are not wasted and the purchased products do not end up in waste. Modern society has become careless in its attitude towards food and buys too many products without considering their effective use. According to the "Estimates of European food waste levels" report, $53 \%$ of all food waste is generated by households (Stenmarck et al., 2016).

In accordance with the objectives of the report "Latvian Bioeconomy Strategy 2030" (Ministry of Agriculture..., 2016) developed at the national level, main development opportunities of the Latvian food industry are as follows:

1) production of quality products;

2) extraction and production of functional food;

3) development and manufacturing of innovative products;

4) creating innovative food development and processing technologies. 
It is also important to make more rational use of raw materials and the produced food, reducing and using wiser the generated waste from raw materials and food.

One of the current challenges is to provide the public with quality food that is both economically accessible and attractive to the consumer in terms of its appearance and taste. In addition, local products, local identity products, and organic products are becoming increasingly important. The second target among the United Nations Sustainable Development Goals is food waste reduction and local farmers support, as one-third of the world's food is wasted, while 821 million or almost $11 \%$ of the world's population is starving, and $40 \%$ of the world's population suffers from water scarcity (United Nations).

Various food preservation technologies, such as pasteurization, sterilization, freezing, drying, and others, can be used to preserve fresh food and its valuable properties for a longer time and to reduce food waste. One of the food drying methods is lyophilization. Lyophilization is the sublimation treatment of food products or drying of products in a molecular dryer (Malik et al., 2018).

Other sources define lyophilization as a method of food preservation that requires first freezing the food, which is then dehumidified in a vacuum. During the lyophilization process, fruits, berries, vegetables, and foods are dried in a vacuum while freezing at low temperatures (Boss et al., 2004). During this process, the frozen water in the food directly transforms into gas, bypassing the liquid phase (sublimation) (Ceballos et al., 2012). This allows the foods retaining their shape, size, colour, aromatic and taste properties while gaining a specific loose and crunchy texture (Ciurzyńska et al., 2011). The taste of the product slightly intensifies compared to products dried by traditional methods (Babić et al., 2009).

Lyophilization is suitable for preserving perishable food or making food more convenient for transportation. This is possible because of refrigeration processes during which the food is frozen and then the pressure is reduced, allowing the frozen water in the material transform directly from the solid to the gas state. During the lyophilization, the product is first frozen and then loaded into a vacuum drying tank, where it is exposed to a vacuum that causes the sublimation of ice, whereas a condenser inside the tank condenses the gas on the spool surface, and the product is dehydrated.

The main advantages of lyophilization:

1) Long shelf life of the product. If the lyophilised product is sealed in special suitable packaging preventing the re-absorption of moisture, the product can be stored at room temperature without refrigeration and preserved for many years. The preservation is possible because the water content of the product is significantly reduced, inhibiting the activity of 
microorganisms and enzymes that would usually damage or destroy the product.

2) Ease of transportation. The lyophilized products are low in weight and properly packaged lyophilized products can be easily transported in standard containers or any other transportation methods commonly used in the industry. Accordingly, a specialized equipment fitted with refrigeration systems or freezers is not required.

3) Improved quality. Lyophilization causes less damage to the substance than other dehydration methods that use higher temperatures. Lyophilization usually does not cause shrinking or hardening of the dried material. In addition, the quality of the product, including its appearance, taste, aroma and nutrient content, is usually preserved, thus, making this procedure popular.

4) High rehydration capacity. Lyophilized products can be rehydrated (restoration of the lost water content) much faster and easier, because the lyophilization process causes the formation of microscopic pores in the product.

Although lyophilization of food products has many advantages over other preservation technologies, its one main disadvantage is related to the costs of the process. For example, in 2020, the price of freeze-dried (lyophilized) fruit on the international market is 4-6 times the price of traditionally dried product (drying and dehydration in hot air, which changes the appearance, chemical structure, taste, and nutritional value of the food). Compared to other food drying methods, lyophilization as a food drying method offers many advantages and is expected to make a major contribution to food preservation in the long term and, with the advancement of technology, to food waste reduction.

Comparing different preservation technologies, it can be seen that lyophilization as the food drying method has significant advantages over other technologies. Table 1 shows an informative comparison in general categories from the end consumer perspective between lyophilization, dehydration, sterilization or pasteurization (canning), and freezing methods: the taste of the processed product comparing to a raw or natural product, the amount of nutrients in the processed product compared to the natural product, colour characteristics comparing to the natural product, the texture of the product after processing compared to the natural product, availability of the product at different times of the year, the shelf life of the product, the use of sugar/sodium in a given food preservation technology, the absolute weight of the product, a need to prepare the product before it can be consumed. The table uses colour coding: green (positive), yellow (neutral), red (negative) and it can be seen that lyophilization has only positive and 
some neutral features and that supports the projected future potential of this technology.

Table 1. Comparison of different preservation technologies (Mercer Foods.com)

\begin{tabular}{|c|c|c|c|c|c|}
\hline & NATURAL & $\begin{array}{l}\text { LYOPHILI- } \\
\text { SATION }\end{array}$ & $\begin{array}{l}\text { DEHYDRA- } \\
\text { TION }\end{array}$ & $\begin{array}{c}\text { Canning } \\
\text { (pasteurization/ } \\
\text { sterilization) }\end{array}$ & FREEZING \\
\hline $\begin{array}{l}\text { TASTE } \\
\text { (comparing to } \\
\text { the natural) } \\
\end{array}$ & $\begin{array}{c}\text { As provided } \\
\text { by nature }\end{array}$ & $\begin{array}{c}\text { Close to the } \\
\text { natural }\end{array}$ & $\begin{array}{c}\text { Similar to the } \\
\text { natural }\end{array}$ & Intensified & $\begin{array}{c}\text { Close to the } \\
\text { natural }\end{array}$ \\
\hline NUTRIENTS & $\begin{array}{c}\text { As provided } \\
\text { by nature }\end{array}$ & $\begin{array}{c}\text { Most } \\
\text { nutrients are } \\
\text { retained }\end{array}$ & $\begin{array}{c}\text { Blanching } \\
\text { reduces some } \\
\text { nutrients }\end{array}$ & $\begin{array}{c}\text { High } \\
\text { temperature } \\
\text { reduces a large } \\
\text { part of nutrients }\end{array}$ & $\begin{array}{c}\text { At a stable } \\
\text { temperature, } \\
\text { many of the } \\
\text { nutrients are } \\
\text { retained }\end{array}$ \\
\hline COLOUR & $\begin{array}{c}\text { As provided } \\
\text { by nature }\end{array}$ & Retained & Slightly pale & Slightly pale & Retained \\
\hline TEXTURE & $\begin{array}{c}\text { As provided } \\
\text { by nature }\end{array}$ & Crunchy & Chewy & Soft & $\begin{array}{c}\text { First hard, then } \\
\text { soft }\end{array}$ \\
\hline SEASONALITY & \begin{tabular}{|c|} 
Depends on \\
the season
\end{tabular} & Year round & Year round & Year round & $\begin{array}{c}\text { Year round, if } \\
\text { stored correctly }\end{array}$ \\
\hline SHELF LIFE & Very short & $\begin{array}{c}\text { Very } \\
\text { extensive }\end{array}$ & $\begin{array}{c}\text { Very } \\
\text { extensive }\end{array}$ & Extensive & Short \\
\hline $\begin{array}{l}\text { ADDED SUGAR/ } \\
\text { SODIUM }\end{array}$ & No & No & Often & Often & Rarely \\
\hline WEIGHT & Heavy & Light & Medium & Heavy & Heavy \\
\hline PREPARATION & Various & No & Rehydrate & Drain & Defrost \\
\hline
\end{tabular}

One of the food segments that most frequently uses lyophilization technologies is the hiking food segment. According to various experts in the hiking industry, such as CleverHiker (a specialized site for hiking tourism) (Cleverhiker, 2020), the use of drying methods is very common in this segment, as it provides two main features required in the segment: a long shelf life and a light weight of the product while ensuring the amount of energy required during the hike. The companies that produce dried food for tourism pay special attention to the energy value of products. As the stress of professional life increases, the number of consumers who opt for hiking and tourism has increased in recent years, leading to an increased demand for dehydrated hiking foods such as pasta, noodles, and meat products. The global dehydrated food market is expected to continue to be driven by such factors as increasing per capita incomes and the growth of the local tourism industry. Given the restrictions on international travel in 2020 due to COVID19 , domestic hiking tourism and the sales of related products are expected to 
increase, including the use of contactless points-of-sale such as vending machines on hiking trails.

Hiking foods are classified based on the meal type (breakfast, principal meal, and snacks) and product category (meat, fish, poultry, pasta, bakery products, fruit and nuts, soups, purees, gluten-free and lactose-free, etc.). Pasta and bakery products currently hold the largest market share, but gluten-free and lactose-free dehydrated foods are expected to experience the fastest grow in the coming years (Dried..., 2018). Table 2 shows the main dehydration or drying technologies used in the hiking food segment. It can be concluded that among the various available technologies, lyophilization offers considerable advantages, but it also requires high costs, long processing time, advanced equipment, and special packaging.

Table 2. Comparison of different drying technologies

(Rodrigues et al., 2016)

\begin{tabular}{|c|c|c|}
\hline Drying method & Advantages & Drawbacks \\
\hline $\begin{array}{l}\text { Sun-drying (open-air): } \\
\text { crops are spread on the } \\
\text { ground and absorb solar } \\
\text { energy }\end{array}$ & $\begin{array}{l}\text { - No investment required, low- } \\
\text { cost technology } \\
\text { - Well-suited for low value- } \\
\text { added products } \\
\text { - Used close to the source of } \\
\text { raw materials }\end{array}$ & $\begin{array}{l}\text { - Contamination is possible } \\
\text { - Weather dependent } \\
\text { - Slow drying } \\
\text { - Requires a significant } \\
\text { workforce } \\
\text { - It may not be possible to } \\
\text { achieve a sufficiently low } \\
\text { level of moisture to avoid } \\
\text { the development of micro- } \\
\text { organisms }\end{array}$ \\
\hline $\begin{array}{l}\text { Solar drying (direct): } \\
\text { solar energy is collected } \\
\text { on a glass surface and } \\
\text { directed to a drying } \\
\text { chamber }\end{array}$ & $\begin{array}{l}\text { - Simple and cheap equipment } \\
\text { - Protected against the weather } \\
\text { effects (rain, etc.) }\end{array}$ & $\begin{array}{l}\text { - Overheating risks resulting } \\
\text { in damage to crops } \\
\text { - Loss of taste } \\
\text { - Not scalable } \\
\text { - Discoloration }\end{array}$ \\
\hline $\begin{array}{l}\text { Solar drying (indirect): } \\
\text { the crops are placed in a } \\
\text { drying chamber and a } \\
\text { dedicated device uses } \\
\text { solar energy to heat the } \\
\text { air discharged into the } \\
\text { drying chamber }\end{array}$ & $\begin{array}{l}\text { - Greater control over the } \\
\text { drying process } \\
\text { - Raw materials are not directly } \\
\text { exposed to the sun } \\
\text { - Suitable for photosensitive } \\
\text { raw materials } \\
\text { - Can be used at high } \\
\text { temperatures }\end{array}$ & $\begin{array}{l}\text { - The expensive equipment } \\
\text { requires a large capital } \\
\text { investment }\end{array}$ \\
\hline Microwave drying & $\begin{array}{l}\text { - Fast drying at low } \\
\text { temperatures } \\
\text { - High thermal efficiency } \\
\text { - Homogeneous drying } \\
\text { - Energy efficient equipment } \\
\text { - Good level of bacteria } \\
\text { elimination }\end{array}$ & $\begin{array}{l}\text { - Small batches of processed } \\
\text { raw materials } \\
\text { - Harmful microwaves } \\
\text { require special precautions } \\
\text { when used }\end{array}$ \\
\hline
\end{tabular}




\begin{tabular}{|l|l|l|}
\hline Spray drying & - Quick drying & - The expensive equipment \\
- Large-scale production & - Low labour costs \\
- Easy maintenance and & operation & $\begin{array}{l}\text { investment } \\
\text { - High energy consumption } \\
\text { - Can only be used for raw } \\
\text { materials that can be } \\
\text { sprayed, e.g. liquids, low- } \\
\text { viscosity slurries, purees }\end{array}$ \\
\hline Vacuum drying & $\begin{array}{l}\text { - Low-temperature drying } \\
\text { - Low risk of oxidation of raw } \\
\text { materials } \\
\text { - Suitable for thermo-sensitive } \\
\text { raw materials } \\
\text { - Mild drying process } \\
\text { - Preserves nutrients }\end{array}$ & $\begin{array}{l}\text { - Hygroscopic final product, } \\
\text { requires special packaging }\end{array}$ \\
& $\begin{array}{l}\text { - Low-temperature drying, } \\
\text { reduced oxidation and } \\
\text { hydrolysis of raw materials } \\
\text { - The final product is light and } \\
\text { porous, well suited for } \\
\text { rehydration } \\
\text { - Suitable for dry and solid final } \\
\text { products - good taste, texture, } \\
\text { and visual properties of the } \\
\text { final product. }\end{array}$ & $\begin{array}{l}\text { - Extremely hygroscopic } \\
\text { final product - requires } \\
\text { special packaging } \\
\text { - Very slow process }\end{array}$ \\
\hline Lyophilisation & $\begin{array}{l}\text { - Sophisticated equipment } \\
\text { - Very expensive process }\end{array}$ \\
\hline
\end{tabular}

It should be emphasized that dehydration is an energy-intensive process. Drying requires a significant amount of energy, which is about 20 to $25 \%$ of the total energy used in food processing, or 10 to $25 \%$ of the total energy used in all sectors (in the developed countries). Accordingly, energy and time efficiency and related parameters in food processing are important (Guiné, 2018). This factor is especially important when using lyophilization, and therefore one of the advantages of the "SUPPIT" (an acronym for "The Technology for the Development of Balanced-Diet Hiking Food" in Latvian) methodology is the optimized cost of the lyophilization process; because, as Table 2 shows, the main disadvantages of lyophilization are drying time and energy expenditure.

The global market offers a variety of lyophilization equipment from various manufacturers, such as Millrock Technology, Inc. (USA), Telstar (USA), GEA Group (Germany), SP Industries, Inc. (USA), Optima Pharma (Germany), Labconco (USA), Buchi (Germany), HOF Sonderanlagenbau GmbH (Germany), and Scala Scientific (the Netherlands). The two main markets in which companies invest in new lyophilization technologies are the United States and Germany. (Global Market ..., 2019) Although the primary market for lyophilisation equipment is the pharmaceutical sector, 
there is a shift on the part of the producers from the pharmaceutical market to the food processing market. The growing market share of lyophilisation equipment in the food industry also directly correlates with the demand from the food industry for an efficient methodology for food industry processes using lyophilization equipment.

However, manufacturers of lyophilisation equipment do not offer to businesses food ingredients and/or preparation methods prior to the lyophilization process that can be used with this equipment. Therefore, the companies that want to start the production of lyophilized food and/or meals need the methodology and know-how for efficient fabrication of a final product for the market and customers. As the lyophilization process must be as efficient as possible to reduce the production costs, the lyophilization equipment also needs to be adapted to the specific methodology used. This is an additional product offered by the merchant that adapts the methodology to the specific lyophilization equipment and vice versa.

One of the uses of lyophilized food is hiking food, which can be further developed for military and aerospace applications. Besides, lyophilization can be used for processing of foods (e.g., fruits, vegetables) prior to the expiration date, which allows the product to be further developed for specific needs. This is in line with the Zero Food Waste movement, which popularizes a change in public attitudes towards food waste promoting waste reduction.

Hiking food must be sized in small, easy-to-use packaging, light, intended for long-term storage, balanced, i.e., containing sufficient amounts of proteins, fat, carbohydrates, vitamins, minerals, etc., and must provide the amount of nutrients according to the complexity of the walk or hike. The advantages of lyophilized hiking food-meal is in the following properties lyophilized food can preserve the colour, aroma, taste, and shape of the food to the maximum; it can preserve the levels of all nutrients in food, especially the thermo-sensitive ingredients. Choosing the appropriate packaging technology for lyophilized foods that provides protection against air and moisture allows achieving long shelf life and high resistance to external biological processes and mechanical effects on the product. Hiking food can be delivered to the consumer through contactless sales channels (parcel terminals, food vending machines, etc.)

The global lyophilization equipment market can be described as a highly consolidated and competitive market dominated by major players. The main market players focus on cooperation with other players. In addition, they invest heavily in research and development to create innovative solutions and gain a competitive advantage.

Lyophilization equipment companies adopt various business strategies to strengthen their position in the market and to increase the company's product revenue, they significantly invest in R\&D of advanced, frozen dried 
products. Launching new products and strategic alliances are key strategies adopted by these players in the industry. The main equipment production market players are concentrated in Germany and the United States. These are also the main markets where companies invest heavily in the development of lyophilization technologies.

Based on equipment technology, the market is segmented into pallettype lyophilizers, collector lyophilizers, and rotary lyophilizers. From the perspective of the scale of operations, the market is segmented into industrial, experimental, and laboratory uses, while from the perspective of possible lyophilization applications, the market is divided into food processing and packaging applications, pharmaceuticals and biotechnology production, medical applications, and others. Based on accessories, the market is divided between the producers of loading and unloading systems, control and monitoring systems, vacuum systems, Clean-in-Place (CIP) systems, drying chambers, lyophilization trays/shelves, collectors, and other elements. (Global Market ..., 2019)

The lyophilization industry is most highly developed in North America, Europe, and the Asia-Pacific region. The main players in Europe are in the following countries: Germany, the United Kingdom, France, Italy, Spain, and the Netherlands. This indicates that compared to Eastern Europe, Western Europe is ahead of the industry in this area.

It is true that the market for lyophilization technologies is developing mainly due to the increasing activity of competitors, including in other European countries with low research, development, and production costs.

One such example is a project launched in Bulgaria in 2017 with a total cost of around EUR 16.5 million, which develops innovative cryogenic technologies and other innovations in cooperation with the Research Institute of the Bulgarian Academy of Sciences, that will result in the creation of a new lyophilized food plant in Levski region for the production of various food categories (mainly from organically certified products) (European Commission, 2018).

\section{Conclusions and proposals}

Lyophilization is suitable for preserving perishable food or making food more convenient for transportation. This is possible because of refrigeration processes during which the food is frozen and then the pressure is reduced, allowing the frozen water in the material transform directly from the solid to the gas state.

The advantages of lyophilized hiking food-meal is in the following properties - lyophilized food can preserve the colour, aroma, taste, and shape of the food to the maximum; it can preserve the levels of all nutrients in food, 
especially the thermo-sensitive ingredients. Choosing the appropriate packaging technology for lyophilized foods that provides protection against air and moisture allows achieving long shelf life and high resistance to external biological processes and mechanical effects on the product. Hiking food can be delivered to the consumer through contactless sales channels (parcel terminals, food vending machines, etc.)

Each industry has its own growth drivers and challenges. In the lyophilization sector, the growth drivers are the following: an increasing demand for lyophilized products, technological advances, rapid expansion of the pharmaceutical and food industries, growing demand for higher-quality products with longer shelf life and stability. The main problems are high installation and maintenance costs of drying equipment, lack of skilled labour, and strict regulatory guidelines.

Food lyophilization equipment manufacturers can consider the opportunity to offer the device to consumers - new clients who are planning or just starting the operation of their companies, i.e. companies that are starting manufacturing lyophilized products, to offer a service which involves the methodology of the food processing technology.

\section{References}

1. Babic, J., Cantalejo, M. J., Arroqui, C. (2009). The effects of freeze-drying process parameters on Broiler chicken breast meat. LWT - Food. Sci. Technol., 42, 1325-1334.

2. Boss, E.A., Filho, R.M., Toledo, E.C. (2004). Freeze drying process: real time model and optimization. Chemical Engineering and Processing: Process Intensification, 43(12), 1475-1485. https://doi.org/10.1016/i.cep.2004.01.005

3. Ceballos, A.M., Giraldo, G.I., Orrego, C.E. (2012). Effect of freezing rate on quality parameters of freeze dried soursop fruit pulp. Journal of Food Engineering, 111(2), 360-365. https://doi.org/10.1016/j.jfoodeng.2012.02.010

4. Ciurzyńska, A., Lenart, A. (2011) Freeze-drying-application in food processing and bioteccnology-a review. Polish Journal of Food and Nutrion, 61(3), 165-171. https:// doi:10.2478/v10222-011-0017-5

5. Cleverhiker (2020). Cleverhiker.com. Retrieved from https://www.cleverhiker.com/

6. Dried Processed Food Market (2018). Infinitum Global Research.

7. European Commission. (2018. Investment Project EIPP-20160238: Freeze-Dried and Lyophilisation Food Plant. Retrieved from https://ec.europa.eu/eipp/desktop/en/projects/project-251.html

8. Galoburda R., Rakčejeva, T. (2008). Pārtikas apstrādes alternatīvie procesi. LLU. Jelgava

9. Global Market Insights (2019). Lyophilization Equipment Market to hit $\$ 8.5$ billion by 2025. Retrieved from https://www.globenewswire.com/newsrelease/2019/09/25/1920474/0/en/Lyophilization-Equipment-Market-to-hit-8-5billion-by-2025-Global-Market-Insights-Inc.html

10. Guiné, R.P.F. (2018). The Drying of Foods and its Effect on the Physical-Chemical, Sensorial and Nutritional Properties. International Journal of Food Engineering, 4(2), 93-100. doi: 10.18178/ijfe.4.2.93-100 
11. Mallik, A, Arman, A.M., Kundu S., et al. (2018). Drying and dehydration technologies: a compact review on advance food science. MOJ Food Process Technol. DOI:10.15406/mojfpt.2018.06.00142

12. Mercer Foods.com (n.d.). Ingredient Guide. Retrieved from http://www.mercerfoods.com/products-services/research-and-development/

13. Ministry of Agriculture Republic of Latvia (2016). Informative Report Latvian Bioeconomy Strategy 2030. Retrieved from https://www.zm.gov.lv/public/files/CMS Static Page Doc/00/00/01/46/58/E275 8-LatvianBioeconomyStrategy2030.pdf

14. Rodriguez, A., Rodriguez M.M., Lemoine, M.L., Mascheroni, R.H. (2016). Study and Comparison of Different Drying Processes for Dehydration of Raspberries. Drying Technology, 35(6), 689-698, https://doi.org/10.1080/07373937.2016.1202958

15. Stenmarck, A., Jensen, C., Quested, T., Moates, F. (2016). Estimates of European food waste levels. Swedish Environmental Research Institute. Stockholm. Retrieved https://www.eu-

fusions.org/phocadownload/Publications/Estimates\%20of\%20European $\% 20$ food \%20waste\%20levels.pdf

16. United Nations (n.d.). The Sustainable Development Goals. Retrieved from https://www.un.org/sustainabledevelopment/sustainable-development-goals/ 